\title{
8. Sınıf İnkılap Tarihi Ders Kitabının Edebi Eserler Açısından Değerlendirilmesi
}

Meltem Elif Çelik ${ }^{a, b}$, Hacer Dolanbay ${ }^{c}$

Özet

Türkiye Cumhuriyeti İnkılap Tarihi nesillere Türk milletinin Kurtuluş Savaşı'nı, milli kahramanlarımızı aktaran bir derstir. İnkılap tarihinin akılda kalıcı öğrenilmesi, dersin amacına ulaşmasını ve öğrenciler tarafından özümsenmesini kolaylaştırmaktadır. Bu bağlamda İnkılap tarihinin daha faydalı ve kalıcı olmasında hikaye, destan, şiir, türkü, röportaj, biyografi gibi edebi eserlerin kullanılması önemlidir. Çalışmanın amacı 2020-2021 eğitim öğretim yılında ülkemizde Milli Eğitim Bakanlığı tarafından okutulan 8. Sınıf inkılap tarihi ve Atatürkçülük ders kitabında yer alan edebi ürünlerin incelenmesidir. Çalışmada nitel araştırma yöntemlerinden doküman analizi kullanılmıştır. Veri kaynağı olarak ise MEB tarafından onaylanmış 2020- 2021 eğitim- öğretim yılında kullanılmakta olan ders kitabı seçilmiştir. Çalışma doğrultusunda elde edilen veriler içerik analizi yöntemi ile çözümlenmiştir. Çalışmanın sonucunda İnkılap Tarihi ders kitabının edebi eserler açısından oldukça cesitlilik arz ettiği ancak kitapta çoğunlukla aynı türde eserlerden yararlanıldığ 1 görülmüştür. Öte yandan Şarkı, türkü gibi duygusal yönden öğrencileri besleyecek türlerden hiç yararlanılmadığı, anı, hikaye ve roman gibi edebi türlerden ise yeterince yararlanılmadığı tespit edilmiştir.
Anahtar Kelimeler

İnkllap Tarihi

Edebi Eserler

Eğitim

Ders Kitabi

Makale Hakkında

Geliş Tarihi: 01.03.2021

Kabul Tarihi: 24.09.2021

Doi: 10.18026/cbayarsos.889305

\section{The Evaluation of the 8th-Grade History Textbook in Terms of Literary Genres}

\begin{abstract}
The history of the revolution of the Republic of Turkey is a lesson that conveys to generations the war of independence of the Turkish nation, our national heroes. The aim of this study is to examine the literary products contained in the 8th-grade history of revolution and Kemalism textbook taught by the Ministry of National Education in our country in the 2020-2021 academic year. Document analysis from qualitative research methods was used in the study. The data were analyzed by content analysis. As a result of the study, the textbook is quite rich in literary works, but the book mostly uses the same types of literacies. On the other hand, it has been found that genres such as songs and folk songs that will feed students emotionally have never been used, and literary genres such as memoirs, stories, and novels have not been adequately used.
\end{abstract}

Keywords

Revolution History

Literary genres

Education

Lesson book

About Article

Received: 01.03.2021

Accepted: 24.09 .2021

Doi: 10.18026/cbayarsos.889305

\footnotetext{
a İletişim yazarı: elifcendek@hotmail.com

b MEB sosyal bilgiler öğretmeni. ORCID: 0000000248502742

c Doktor öğretim üyesi, Muş Alparslan Üniversitesi. ORCIDD: 0000000294085636
} 


\section{Giriş}

Türkiye Cumhuriyeti İnkılap Tarihi ve Atatürkçülük, eğitim- öğretimin çeşitli kademelerinde okutulan bir derstir. Ortaokul 8. Sınıf da bu eğitim- öğretim kademelerinden birini teşkil etmektedir. İnkılap tarihi dersinin amacı milli mücadeleyi gerçekleştiren ve inkılapları oluşturan kurucuları yeni nesillere tanıtmak, inkılapların korunmasını ve devamlılı̆̆ını sağlayacak nesiller yetiştirmektir (Hatipoğlu, 2004). Milli mücadele için yapılan fedakârlıklar, Atatürk'ün lider olmasını sağlayan özellikleri, Cumhuriyet yönetiminin nitelikleri de derste öğrencilere kazandırılmak istenen bilgiler arasındadır (Yıldırım, Mert, 2019). Bu bilgilerin öğrencilere kazandırılması ile nesillerin inkılapların altındaki felsefeyi, cumhuriyete yönelik olumlu tutum ve anlayış geliştirmeleri amaçlanır (Altıkulaç, 2014).

İnkılap Tarihi dersinin bu amaçları gerçekleştirmek amacıyla eğitimde yer alması 1925 yılına kadar uzanır. İlk olarak 1925'te "İhtilaller Tarihi" adı ile okutulmaya başlanmıştır (Kaymakçı, Er, 2009). 1926' da Edebiyat Fakültesi'nde Türkiye İnkılabı Tarihi dersi konulmuştur. 1931'den sonra lise ve öğretmen okullarında Türk İnkılabı ve Cumhuriyet Devri Tarihi dersi konulmuştur (Sever, 2017). Ders bir düzen içinde okutulmaya 1933 yılında başlamıştır. 1933'te Türk gençlerine milli politikamız hakkında bilgi vermek amacıyla İstanbul Üniversitesi bünyesinde Türk İnkılap Enstitüsü kurulmuştur. (Yılmaz, belirtilmemiş). 1934'te ise üniversitelerde İnkılap Tarihi dersleri okutulmaya başlanmıştır. Atatürk ilke ve inkılapları 1936'da ilköğretim programlarına Atatürk ilke ve inkılaplarını öğretmek amacıyla tam olarak girmiştir (Ata, 2014). 1942 ile 1980 tarihleri arasında "İnkılap Tarihi ve Cumhuriyet Rejimi" adıyla İnkılap Tarihi enstitülerinde ders olarak verilmiştir. 1981'de Talim Terbiye Kurulu'nun 76 sayılı kanunu ile ortaokullarda yer alan son sınıflarda Türkiye Cumhuriyeti İnkılap Tarihi dersi konulmuştur. 1982' de ise Atatürkçülük kavramı da eklenmiştir (Alaca, 2017). 1999'da dersin adı İkinci Dünya Savaşı ve Türkiye başlığı Atatürkçülük yerine konulmuştur. 2005'te Yapılandırmacı yaklaşımın kabul edilmesi ile 1981 tarihinde kabul edilen İlköğretim TC İnkılap Tarihi ve Atatürkçülük dersi öğretim programı yürürlükten kaldırıldı. 2005'te yapılandırmacı yaklaşım kabul edilerek ders ezberci ve geleneksel öğretim anlayışından kurtarılmış, yaparak- yaşayarak ve öğrenciyi aktif kılan yöntemlerle zenginleştirilmiştir. 20082009 eğitim- öğretim yılında ise 2005'te kabul edilen program uygulamaya konulmuştur. 2012'de 4+4+4 sistemine geçiş yapılarak İnkılap Tarihi dersi 8. Sınıfta okutulmuştur (Kaymakçı, Er, 2009).

2018 yılında uygulamaya konulan TC İnkılap Tarihi ve Atatürkçülük ders kitabında yer alan üniteler "Bir Kahraman Doğuyor", "Milli Uyanış, Bağımsızlık Yolunda Atılan Adımlar", "Milli Bir Destan, Ya İstiklal Ya Ölüm”, "Atatürkçülük ve Çağdaşlaşan Türkiye" , "Demokratikleşme Çabaları", Atatürk Dönemi Türk Dış Politikası" , "Atatürk'ün Ölümü ve Sonrası" dır (MEB, 2018). Programda toplamda 39 kazanım yer almaktadır.

Tarih derslerinin, soyut ve olgu aktarımı esasına dayanan bir anlayışla öğretilmesi, tarih öğretiminde karşılaşılan en önemli problemlerden biridir. Öğrenciler, yaşadıkları dönemden çok uzak zaman dilimleriyle ilgili konular hakkında, genelde sözlü anlatıma dayalı olarak, soyut bir biçimde bilgilendirilmektedir. Bu tarz bir öğretim şekli, bazı öğrencilerin ilgilerini ve meraklarını istenilen düzeyde uyandıramamakta ve derse karşı olumsuz tutum sergilemelerine sebep olmaktadır (Demircioğlu, 2005).

Tarih konuları geçmişe dönük olduğu ve daha soyut kavramlar içerdiği için öğrencilerin akılda tutması zor olmaktadır. Öğrenciler yaşadıkları dönemden uzak bir zamanla ilgili konuları sadece sözlü anlatımla duyduklarında kavramlar havada kalmakta ve öğrenci duygu ve düşünce olarak tarihsel konuya tam olarak kendilerini verememektedir (Öztaş, 2018). 
İnkılap tarihi dersi de soyut kavramların, geçmişe dönük bilgilerin aktarıldığ Öğrenciler de böyle bir durumda derse karşı ilgisiz kalmaktadır. Bu açıdan dersin ve ders kitabının temel bir kaynak olarak zengin olması ve konuyu somutlaştırması önem taşımaktadır. Öğrencilerin derse karşı olumlu tutum geliştirmesi ve tam öğrenmenin gerçekleştirilmesi için derslerde farklı kaynaklara yer verilmesi önem arz etmektedir (Altıkulaç, 2014). Ders kitaplarında ve derslerde öğretim ortamını zenginleştiren, öğrenmenin kalıcılığını sağlayan kaynakların başında edebi eserler gelmektedir (Çalışkan, Coşkun, 2016). Sanat kaygısı ile oluşturulan yazınsal türlere edebi eser adı verilmektedir (Şimşek, 2014). Edebi eserler yoluyla duygu ve düşünceler, sanatsal yolla gelecek nesillere aktarılmaktadır. Edebi ürünler denilince akla anı, efsane, roman, günlük, mektup, gezi yazısı, makale, fabl, destan, masal, hikaye, siyasetname, şiir, tiyatro, biyografi, söylev ve otobiyografi gelmektedir( Beldağ, Aktaş, 2016). 20. yüzyılın başından günümüze kadar gelen süreçte edebi eserlerin eğitim- öğretimde kullanılması artmıştır. Edebi eserle öğrencilerde estetik duyguları, eğlenceli geçirdiği vakti ve kültürüne dair bilinci arttırmaktadır (Karatay, 2007). Edebi eserler yazılı anlatım ve sözlü anlatım türleri olmak üzere ikiye ayrılmaktadır. Aşağıdaki kavram haritasına bakıldığında edebi türlerin ayrımı ve çeşitleri daha iyi görülecektir.

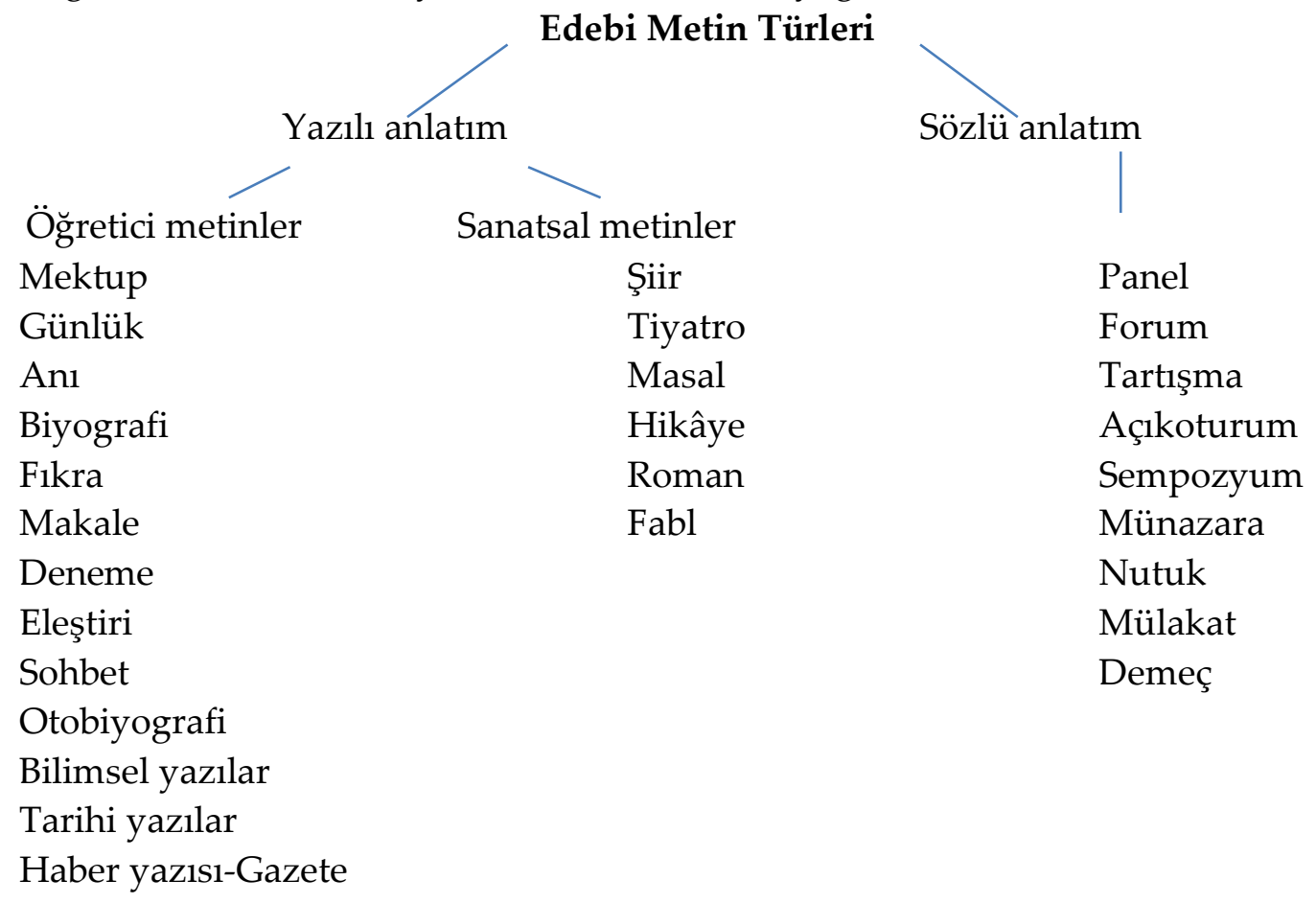

Şekil 1. Edebi türlerin gösterimi

İnkılap tarihi dersinde özellikle edebi eserlerin kullanımının öğrencilere pek çok faydası bulunmaktadır. Dersin daha etkili olmasını sağlarken kalıcılığı da arttırmaktadır. Öğrencilerin bilgiler üzerine düşünmesini, duygu ve düşüncelerinin gelişmesini sağlamaktadır. Bu konuyla ilgili daha önce yapılan çalışmalara bakıldığında Beldağ ve Aktaş'ın 2016'da sosyal bilgiler öğretiminde edebi eserlerin kullanımı ile ilgili çalışmalarında sosyal bilgilerde edebi eser kullanımının dersin amacını gerçekleştirmesine katkıda bulunduğu sonucuna ulaşmışlardır. Ceran'ın 2015'te çocuklara rol model olması bakımından milli mücadele kahramanları ve edebi eserlere yansımasını araştırdığı çalışmasında milli kahramanlara edebi eserler yoluyla yer verilmesinin öğrencilerde liderlik, sabır, sorumluluk gibi özellikleri geliştirdiği ortaya 
çıkmıştır. Boyraz'ın 2019'da 8. Sınıf İnkılap Tarihi ders kitaplarında hatıratların durumunu araştırdığı çalışmasında edebi türlerden biri olan hatıratların İnkılap Tarihi ders kitabında kullanılmasının dersin kalıcılığına öğrenme süreçlerine ve karakter oluşumuna olumlu katkı yaptığından bahsedilmiştir. Aynı çalışmada hatıratların bu faydalarına rağmen ders kitabında yeterince yer bulamadığı sonucuna ulaşılmıştır. Altınkulaç'ın 2014'te doktora tezi olarak yaptığı hatıratların İnkılap Tarihi ve Atatürkçülük dersinde kullanımının öğrenme sürecine etkisini araştırdığı çalışmasında hatıratların derste kullanımının İnkılap Tarihi dersine karşı olumlu tutumları arttırdığı, öğrencilerin analiz ve yorumlama becerilerini geliştirdiği sonucunu bulmuştur. Özpek' in 2020'de tarihi romanların İnkılap Tarihi dersinde kullanımı ile ilgili yüksek lisans tez çalışmasında tarihi romanların öğrencilerin karakter ve değer gelişimine katkı sağladığı, dersi destekleyici ve derse katkı sağlayıcı nitelikte olduğu saptanmıştır. Öztaş (2018) "Tarih derslerinde bir öğretim materyali: Edebi Ürünler" adlı çalışmasında tarih derslerinde edebi ürünlerin kullanılmasının tarih derslerine karşı olumlu tutum gelişimine katkı sağlayacağını, öğrencilerin derse karşı ilgilerini arttıracağını ifade etmiştir. Tarih derslerinde atasözleri, biyografi, deneme, destan, efsane, hatırat, tarihsel hikayeler, mektup, siyasetname, şiir ve masallardan yararlanılabileceğini belirtmiştir. Top, 2009'da İnkılap tarihi derslerinde edebi ürünlerin kullanımının öğrenci başarısına etkisini araştırdığı yüksek lisans tez çalışmasında edebi ürünlerin İnkılap Tarihi derslerinde kullanılmasının deney grubunun başarısına olumlu etki yaptığı̆, öğrencilerde temel beceri ve değerlerin gelişimini sağladığı sonucuna ulaşmıştır. Kaymakçı'nın 2013'te sosyal bilgiler ders kitaplarında edebi eserlerin kullanım durumlarını incelediği araştırmasında sözlü ve yazılı edebi eserlerin kullanılmasına önem verildiği anlaşılmıştır. Mektuptan, siyasetnameye, şiirden, tekerlemeye kısacası pek çok türün 4, 5, 6 ve 7. Sınıf ders kitaplarında yer aldığ görülmüştür.

Bu konu ile ilgili daha önceki çalışmalara bakıldığında İnkılap Tarihi ders kitabı pek çok çalışmada tek bir edebi tür bakımından incelendiği görülmüştür. Bunun yanında İnkılap Tarihi dersine ilişkin araştırmaların ortaöğretim düzeyine yoğunlaştığ 1 tespit edilmiştir (Çeçen, Berk, 2019; Dönmez, Yazıcı, Uslu,2015; Öztaş, 2018; Yılmaz, 2005). Bizim çalışmamız ise ortaokul İnkılap Tarihi ders kitabını edebi türlerin çeşitliliği bakımından inceleyecektir. Çalışma İnkılap Tarihi ders kitabını edebi türler açısından tamamen inceleyeceği için ve ortaokul 8. Sınıf ders kitabına odaklandığı için önemlidir. Çalışmada aşağıdaki problemlere yanıt aranmıştır:

a. 8. Sınıf İnkılap tarihi ders kitabında yer alan edebi eserler nelerdir?

b. 8. Sınıf İnkılap tarihi ders kitabında yer alan edebi eserlerin ünitelerdeki dağılımı nasildir?

\section{c. Yöntem}

Çalışmanın bu bölümünde araştırmanın modeli, araştırmanın deseni, verilerin toplanması ve verilerin analizi hakkında bilgi verilmektedir.

\section{Araştırma Modeli}

$\mathrm{Bu}$ araştırmada nitel araştırma modeli kullanılmıştır. Nitel araştırma gözlem, görüşme, doküman analizi gibi veri toplama yöntemlerinden yararlanılan ve bu sayede çalışma grubunun algılarının ortaya çıkartıldığı bir modeldir (Yıldırım, Şimşek, 2018). Bir başka söylem ile ifade edilecek olursa nitel araştırmalar kuram oluşturma amaciyla toplanan 
verilerin ışığında daha önceden bilinmeyen sonuçlar arasında ilişki kurarak olayları açıklama modelidir (Glasser, 1978).

\section{Araştırmanın Deseni}

$\mathrm{Bu}$ çalışmada nitel araştırma modellerinden doküman analizi kullanılmıştır. Araştırılması hedeflenen olgu/olgular hakkında bilgi içeren yazılı materyallerin çözümlemesini kapsaması ve araştırmanın farklı boyutlarına odaklanmayı sağlaması ve araştırmanın amaçlarına uygunluğu nedeniyle (Ekiz, 2010) doküman analizi yöntemi tercih edilmiştir. Mektup, resmi yazılar, biyografiler, anılar, kitaplar, dergiler, günlükler, arşiv belgeleri doküman analizi kapsamına giren türlerdir (Balc1, 2007). Bu çalışmada 2020-2021 eğitim öğretim yılında kullanılan Türkiye Cumhuriyeti İnkılap Tarihi ve Atatürkçülük ders kitabının edebi eserlerin kullanımı açısından inceleneceğinden doküman analizi kullanılmıştır.

\section{Veri Toplama Araçları}

8.sınıflarda okutulmak için belirlenen ve Milli Eğitim Bakanlığı ile Talim Terbiye Kurulunca onaylanmış üç ders kitabı vardır. Bu çalışmada üzerinde çalışılacak kitap olasılık temelli örnekleme yöntemlerinden seçkisiz yöntemle belirlenmiştir. Üç ders kitabı içinden incelenmek üzere 2020-2021 eğitim öğretim yılında 8.sınıf İnkılap tarihi dersinde okutulan Türkiye Cumhuriyeti İnkılap Tarihi ve Atatürkçülük MEB yayını seçilmiştir. Çalışmada seçilen ders kitabı konuların anlatımında yer verilen edebi eserler açısından ünite bazında incelenmiştir. Edebi eserler ile ilgili kavramlar kitapta belirlenmiş, veriler kodlanmış ve ait oldukları temalar bulunmuştur. Daha sonra kod ve temalar düzenlenmistir. Ders kitabı araştırmacılar tarafından detaylıca taranarak edebi eserlerin türü belirlenmiştir. Çalışmanın inandırıcılığının ve nesnelliğinin arttırılmasında geçerlik ve güvenirliğin sağlanması önemlidir. Çalışmanın geçerliliğini güvenliğini sağlamak adına kitap iki alan uzmanı araştırmacı tarafından da incelenmiştir. Kitaptaki edebi eserler kodlanarak temalara ulaşılmıştır. Ardından ulaşılan kodlar ve ilişkide olduğu temalar karşılaştırılmıştır. Araştırmaçların ulaştı̆̆ arasında \% 80 uyum olduğu görülmüştür. Araştırmanın güvenirliği hesaplanırken (Güvenirlik= Görüş Birliği/ Görüş Birliği+ Görüş Ayrılığı) formülü kullanılmıştır (Miles ve Huberman,1994). Çalışmada tarih alanında yazılmış kitaplar tarihi yazılar olarak sınıflandırılırken genel ağ kaynaklı resmi sitelerden alınan yazılar bilimsel yazılar olarak sınıflandırılmıştır. Demeçler ise Atatürk'e ait sözlerin yer aldığı bölümdür. Türkçeye çevrilmemiş sadece görsel olarak verilmiş Osmanlıca gazete görselleri öğrenci tarafından okunamadığı için metin türü olarak sayılmamıştır.

\section{Verilerin Toplanması ve Analizi}

Doküman analizi yöntemiyle elde edilen veriler içerik analizi ile çözümlenmiştir. İçerik analizi, toplanan verilerin açıklanmasını kolaylaştıracak kavram ve ilişkilere ulaşılmasını sağlar (Yıldırım ve Şimşek, 2018). Bilim kavramlardan oluşur, kavramlar temalara ulaşılmasını kolaylaştırır ve temalar yoluyla olgular daha iyi anlaşılabilir (Strauss ve Corbin, 1990). İçerik analizinde amaç birbirine benzeyen verileri okuyucunun anlayacağı şekilde kavram ve temalar altında bir araya getirmektir. İçerik analizinde elde edilen veriler; verilerin kodlanması, temaların bulunması, kodların ve temaların düzenlenmesi, bulguların tanımlanması ve yorumlanması aşamalarından geçirilerek kullanılır (Dilek, Baysan ve Öztürk, 
2018). Çalışmada ulaşılan veriler yüzdelik olarak ifade edilerek frekans değerleri tabloda belirtilmiştir.

\section{Bulgular}

a. Inkılap Tarihi Ders Kitabında Kullanılan Edebi Eserlere İlişkin Bulgular

İnkılap Tarihi ders kitabı edebi eserler açısından incelenmiştir. Ders kitabında yer verilen edebi türler aşağıdaki tabloda sınıflandırılmıştır.

Tablo 1. İnkılap Tarihi Ders Kitabında Geçen Edebi Türler

\begin{tabular}{lcc}
\hline \multicolumn{1}{c}{ EDEBİ TÜRLER } & FREKANS & YÜZDE \% \\
\hline Nutuk - Söylev & 28 & 21 \\
Tarihi yazılar (kitaplar) & 37 & 27 \\
Anı & 5 & 4 \\
Biyografi & 1 & 1 \\
Bilimsel yazılar & 7 & 5 \\
Haber yazısı- gazete & 8 & 6 \\
Şiir & 1 & 1 \\
Demeç & 47 & 34 \\
Makale & 2 & 1 \\
\hline Toplam & $\mathbf{1 3 6}$ & $\mathbf{1 0 0}$ \\
\hline
\end{tabular}

Tablo 1 incelendiğinde edebi türlerden özellikle yazılı bilgilendirici metinlere fazlaca yer verildiği görülmektedir. Ders kitabı hazırlanırken kitap içinde yer verilen öğretici ve sanatsal edebi metinlerin toplamı 136'dır. Bu sayı azımsanamayacak ölçüdedir. Bu durum İnkılap Tarihi ders kitabının bilimsel özelliğini arttırmıştır. Ders kitabı verilerinden 37'si tarihi yazı özelliği taşıyan tarihi kitaplardır. Kitapta tarihi kaynaklardan sıkça yararlanılması kitabın niteliğine olumlu katkı sağlamaktadır. Ancak yine kitap incelendiğinde "Amasya Genelgesi, Erzurum Kongresi, Sivas Kongresi" ve "Amasya Görüşmeleri" ile ilgili bilgiler verilirken yalnızca bu konulara ilişkin maddelere yer verilmiş o dönemin ruhunu yansitan ya da öğrencinin konuyu ve o dönemin atmosferini aktaran herhangi bir anıya, gazete haberine, hikâyeye veya günlüğe yer verilmezken yararlanılan edebi eserlerin kaynakları her sayfanın altında veya metnin içinde verilmiştir. Bu öğrencilere konu ile ilgili bilgilerini arttırma amacıyla okuyabileceği veya yararlanabilecekleri kaynaklar hakkında bilgi vericidir. Nutuk yapılan inkılapların ve 19 Mayıs 1919'dan itibaren yaşanılanların yer aldığı önemli bir kitaptır. Kitap incelendiğinde "Nutuk" adlı eserden de pek çok kez yararlanıldığı göze çarpmaktadır. Atatürk'ün kitabın yazarı olarak ve millete hesap verme gayesiyle yazdığı eserden yararlanmak kitabın daha iyi bir anlatıma sahip olmasını sağlamıştır. Kitabın tamamında sanatsal metinlere yalnızca bir kere yer verildiği görülmektedir. Sanatsal metinlerden şiir tarihi konular anlatılırken coşku ve heyecanı arttırabilecek özelliğe sahiptir. Ancak ders kitabında bir defa yer verilmesi coşku ve heyecanı arttırma açısından yetersiz kalmıştır. Bilgilendirici metinler içinde yer alan makale 2 kez yararlanılan kaynak olmuştur. Makaleler 
kitaplardan daha öz bir şekilde derleme bilgiler sunmaktadır. Kitapta makalelere az yer verilmiş öte yandan kaynak kitaplardan oldukça fazla yararlanılmıştır. Sözlü anlatım türlerinden demeç kırk yedi kez kullanılmış ve konular ile alakalı gerek Atatürk'ün gerek o dönemde yaşayanların sözlerine sık sık yer verilmiştir. Bu açıdan bakıldığında demeçler konunun anlatımını güçlendirmiştir. Öğrencilerin konuyu özet şeklinde anlamasını kolaylaştırmıştır. Biyografi ders kitabında 1 defa yararlanılan kaynak olmuştur. Halbuki biyografiler dönemin ruhunun ve tarihsel kişiliklerinin anlatımında önemli yer tutmaktadır. Konulara ilişkin kişilerin biyografisine yer verilmesi kaynak gösterme ve kitap bibliyografisi açısından daha iyi bir örnek oluşturulabilirdi. Anı türüne kitapta 5 kez yer verilmiştir. Anılar dönemin daha iyi anlaşılması, insanların ne yaşadıklarını ve hissettiklerini somut bir şekilde görmeleri, hissetmeleri açısından önemli kaynaklardır. Bu açıdan daha fazla yer verilmesi kitapta geçen konuların daha iyi anlaşılmasını sağlayacaktır.

b. İnkılap Tarihi Ders Kitabı Ünitesi / ünitelerinde En Çok Yer Verilen Edebi Eserlere İlişkin Bulgular

İnkılap tarihi ders kitabında pek çok bilgilendirici metin türünde eserlerden yararlanılmışken bu türlere ünite bazında ne kadar yer verildiği bu soru etrafında incelenmiştir. Aşağıdaki tabloda ünite bazında ne kadar edebi tür kullanıldığı bilgisi yer almaktadır.

Tablo 2. İnkılap Tarihi Ders Kitabının Ünite Bazında Edebi Türleri Gösteren Tablo.

\begin{tabular}{|c|c|c|c|}
\hline EDEBİ TÜRLER & ÜNITTE ADLARI & FREKANS & YÜZDE \% \\
\hline Nutuk - Söylev & Bir Kahraman & 7 & 78 \\
\hline Tarihi yazılar (kitap) & Doğuyor & 2 & 22 \\
\hline Toplam & & 9 & 100 \\
\hline Anı & & 2 & 11 \\
\hline Demeç & & 2 & 12 \\
\hline Tarihi Yazı & Milli Uyanış: Bağımsızlık & 7 & 41 \\
\hline Biyografi & Yolunda Atılan Adımlar & 1 & 6 \\
\hline Bilimsel Yazı & & 2 & 12 \\
\hline Nutuk-söylev & & 2 & 12 \\
\hline Gazete & & 1 & 6 \\
\hline Toplam & & 17 & 100 \\
\hline Anı & & 3 & 12 \\
\hline Bilimsel yazı & & 3 & 12 \\
\hline Tarihi yazı & Milli Bir Destan: Ya İstiklal & 9 & 36 \\
\hline Nutuk-söylev & Ya Ölüm & 8 & 32 \\
\hline Demeç & & 1 & 4 \\
\hline Şiir & & 1 & 4 \\
\hline Toplam & & 25 & 100 \\
\hline
\end{tabular}




\begin{tabular}{|c|c|c|c|}
\hline Gazete & & 1 & 3 \\
\hline Demeç & Atatürkçülük ve & 21 & 68 \\
\hline Nutuk-söylev & Çağdaşlaşan Türkiye & 3 & 10 \\
\hline Tarihi yazı & & 6 & 19 \\
\hline Toplam & & 31 & 100 \\
\hline Nutuk- Söylev & & 4 & 45 \\
\hline Demeç & Demokratikleşme & 3 & 33 \\
\hline Tarihi yazı & Çabaları & 2 & 22 \\
\hline Toplam & & 9 & 100 \\
\hline Demeç & & 10 & 59 \\
\hline Tarihi yazı & Atatürk Dönemi Dış & 3 & 17 \\
\hline Makale & Politikası & 2 & 12 \\
\hline Gazete & & 1 & 6 \\
\hline Bilimsel yazı & & 1 & 6 \\
\hline Toplam & & 17 & 100 \\
\hline Nutuk- Söylev & & 4 & 14 \\
\hline Gazete & & 5 & 18 \\
\hline Tarihi yazı & Atatürk'ün Ölümü ve & 8 & 29 \\
\hline Bilimsel yazı & Sonrası & 1 & 3 \\
\hline Demeç & & 10 & 36 \\
\hline Toplam & & 28 & 100 \\
\hline Genel toplam & & 136 & 100 \\
\hline
\end{tabular}

Ders kitabı üniteler bazında değerlendirildiğinde edebi metinlerin üniteler arasındaki dağılımının orantısız olduğu göze çarpmaktadır. Bazı ünitelerde demeçlere çok yer verilirken bazı ünitelerde tarihi yazılara yer verildiği görülmektedir. Bu durumun ünitede yer alan konuların içeriğinden kaynaklandığı düşünülmektedir. Üniteler gazete haberi açısından incelendiğinde en fazla gazete haberine "Atatürk'ün Ölümü ve Sonrası" ünitesinde yer verildiğ görülmektedir. bu durumun Atatürk'ün ölümü ile ilgili gazete haberlerinin ve onun liderliğine yönelik söylemlerin tarihi bir kanıt olarak sunulmak istenmesinden olduğu sanılmaktadır. Gazete haberleri yazıldığı döneme ışık tutma açısından çok önemli bir tarihi kanıt niteliği taşımaktadır. Öte yandan gazete haberlerinin kimisi kitapta okunaklıyken kimisi okunaklı değildir. Gazete haberleri daha okunaklı olursa ve kitabın konuya ilişkin bir bölümünde yer alırsa daha faydalı olacaktır. Üniteler arasında en çok edebi türe ise otuz bir frekans ile "Atatürk ve Çağdaşlaşan Türkiye" ünitesinde yer verildiği görülmektedir. Özellikle yararlanılan sözlü metin türü demeçtir. Bu ünitede daha çok kabul edilen ilkeler ve yapılan inkılaplar yer aldığı için birinci ağızdan inkılaplara yönelik bilgiler içeren Atatürk'ün demeçlerine yer verilmiştir. Demece en az yer verilen ünite ise "Milli Bir Destan: Ya İstiklal Ya 
Ölüm" olmuştur. Bu ünitede daha çok milli mücadele, cepheler, anlaşmalar anlatıldı̆̆ından o dönemin ruhunu yansıtan bir şiire ve o döneme kaynaklık eden pek çok tarihi yazıya yer verilmiştir. Üniteler arasında en az edebi esere "Bir Kahraman Doğuyor" ve "Demokratikleşme Çabaları" adlı ünitelerde yer verildiği görülmektedir. İki ünitede de 9 kez edebi türlerden yararlanılmıştır. "Bir Kahraman Doğuyor" ünitesi Mustafa Kemal'in hayatının anlatıldığı bir ünitedir. Bu ünitede Mustafa Kemal'in çocukluk ve gençlik yıllarına ilişkin anılara daha fazla yer verilmesi konuya ilgiyi arttırma açısından fayda sağlayacaktır. Üniteler arasında anı türüne tabloda yalnızca "Milli Uyanış: Bağımsızlık Yolunda Atılan Adımlar" ve "Milli Bir Destan: Ya İstiklal Ya Ölüm" ünitelerinde yer verildiği görülmektedir. Anı türü yaşandığı döneme kaynaklık etme açısından önemli bilgilendirici yazılı türdür. Atatürk'ün ilke ve inkılaplarını halka yaydığı dönemi anlatan "Atatürk ve Çağdaşlaşan Türkiye" ünitesinde de anılara yer verilmesi o dönemde yaşanılan olayları anlama inkılapların hangi ortamda gerçekleştiğini anlama açısından fayda sağlayacağı düşünülmektedir. En az kullanılan edebi tür üniteler bazında incelendiğinde 1 frekansı ile biyografidir. Biyografi türü "Milli Uyanış: Bağımsızlık Yolunda Atılan Adımlar" ünitesinde kullanılmıştır. Biyografiler önemli kişileri tanıtan edebi türlerdir. İnkılap tarihi ders kitabında biyografilerin de tarihsel kişiliklerin anlaşılmasında fayda sağlayacağı düşünülmektedir.

\section{Tartışma}

Edebiyat insan ruhunu besleyen, duygu ve düşüncelerini geliştiren bilimdir. Edebi ürünler aracılığı ile insanlar yaşamadığı bir döneme yolculuk yapar, başka hayatlar ile empati kurar, kelime dünyasını geliştirir. Derslerde edebi ürünlerin kullanılması derse karşı ilgiyi arttırır, dersi zenginleştirir, dersleri sıkıcılıktan kurtarır (Akkuş, 2007).

Tarih dersi soyut kavramların ve olayların zengin olduğu bir derstir. 8. Sınıf İnkılap Tarihi dersinin öğrenci görüşlerine göre ve öğrenci başarısına etkisinin değerlendirildiği pek çok çalışma vardır (Özpek, 2020; Öztürk, 2002, Dağaşan, 2019). Bu konuda Kılcan, Palaz ve Gülbudak'ın (2019) yaptığı İnkılap Tarihi derslerine ilişkin öğrenci görüşlerini araştırdıkları çalışmalarında 8. Sınıf öğrencilerinin İnkılap Tarihi dersini sıkıcı bir ders olarak tanımladıkları görülmüştür. Bir diğer bulguya göre, İnkılap tarihi ders kitabında öğretici edebi ürünlerden anılara, gazetelere, tarihi yazılara, söylev ve demeçlere yer verildiği görülmüştür. Ancak derse karşı ilgiyi arttıracak roman, hikâye, mektup, günlük gibi metinlere hiç rastlanmamıştır. Bu türlere yer verilmesi ders kitabının daha etkili ve derse karşı öğrenci ilgisini arttırıcı etki yapabilir. Öztürk'ün 2002'de yaptığı yüksek lisans tez çalışmasında tarih öğretiminde tarihsel romanların kullanılmasının öğrencilerin bilgi ve kavrama düzeylerini arttırdığı sonucuna ulaşılmıştır. Yine 2007'de Akkuş'un tarihsel romanların tarih öğretiminde kullanılmasına ilişkin doktora çalışmasında tarihsel romanların tarihi kavramların öğretiminde olumlu etkisi olduğu, öğrencilerin derse karşı ilgi ve başarısını arttırdığı sonucu ortaya çıkmıştır. Özpek 2020 'de yaptığı yüksek lisans tez çalışmasında tarihi romanların sosyal bilgiler ve İnkılap Tarihi dersi öğretiminde kullanılmasının kültürel miras ve tarihi konuların aktarımı açısından ilişkisi incelemiştir. Çalışması neticesinde tarihi romanların İnkılap Tarihi dersinde yer alan konulara yönelik belirlendiği takdirde derse karşı ilgiyi ve başarıyı arttırdığı sonucu elde edilmiştir. Aynı çalışmada İnkılap tarihi dersine uygun tarihsel romanlar belirlenmiştir. Bu kitapların kısa bir bölümüne veya alıntısına İnkılap Tarihi ders kitabında yer verilmesi ders kitabını içerik yönünden zenginleştirebilir ve öğrencinin kitaba yönelik okuma isteğini arttırabilir. Tarihsel romanların tarih öğretimine olumlu etkisine yönelik araştırmalar mevcutken İnkılap Tarihi ders kitabında roman türüne yer verilmemesi düşündürücüdür. Dağaşan'ın 2019'da inkılap tarihi dersinde tarihi günlük kullanımının öğrencilerin ders 
başarısına etkisini araştırdığı deneysel çalışmasında günlüklerden yararlanmanın dersin kalıcılığını arttırdığı, kolay ve zevkli hale gelmesini sağladığı sonucu ortaya çıkmıştır. Tarihi günlüklerden ders kitabında yararlanılması kitabın içeriğini zenginleştirerek, konuyu daha çekici hale getirebilir.

Anılar insanların yaşadığı döneme yönelik başından geçen olayları anlattığı öğretici edebi türlerdir. İnkılap tarihi ders kitabı incelendiğinde anılardan 5 kez yararlanıldığı görülmüştür. Kitabın anı metin türü açısından zengin olmadığı söylenebilir. Hatıratlar (anı) öğreticiliği arttıran ve birinci elden kaynak niteliği taşıyan edebi türdür. Anıların İnkılap Tarihi dersinde kullanımının pek çok faydası vardır. Öğrencinin empati kurabilmesini, yaşanan dönemdeki ruh halini yazan aracılığı ile anlamasını sağlar. Yaşanılan dönem hakkında da bilgi verir. Ancak ders kitabında yeterli düzeyde kullanılması öğrencinin ders kitabındaki anı metnini okuduğunda konuyu daha kolay anlamasını ve bilgiyi aklında tutmasını sağlayacaktır. Bu konuda Dönmez , Yazıcı ve Uslu (2015) hatıratların tarih öğretiminde kullanımına yönelik çalışma yapmışlardır. Araştırmalarında tarih öğretiminde hatıratların kullanılmasının öğretmenler tarafından olumlu görüldüğü, öğrencilere geçmişe dönük bakış açısı kazandırdığı, İnkılap Tarihi ders hedeflerinin gerçekleşmesine katkı sağladığı bulgularına ulaşmışlardır. Doğan'ın 2016'da yaptığı çalışmada hatıratların insanın kendi hayat tecrübelerinden doğduğu, öğretici yönü güçlü olan birinci elden kaynak niteliği taşıdığ vurgulanmıştır. Bu bağlamda inkılap tarihi ders kitabı değerlendirildiğinde hatıratlara (anı) yer verme açısından yetersiz olduğu söylenebilir.

8. sınıf İnkılap Tarihi dersine edebi ürünlerin kullanımı ile ilgili öğretmen görüşleri de bulunmaktadır. Çencen ve Berk'in 2014'te yaptığı İnkılap Tarihi derslerinde şiir kullanımına ilişkin öğretmen görüşlerini araştırdıkları çalışmalarında öğretmenlerin İnkılap Tarihi dersinde şiir kullanımının dersin başarıya ulaşmasında etkili olduğu, öğretmenlerin şiiri dersin kazanımlarının gerçekleşmesinde yararlı buldukları sonucuna ulaşmışlardır. Bu çalışmada ulaştı̆̆ımız bulgular değerlendirildiğinde İnkılap Tarihi ders kitabında yalnızca bir şiir kullanıldığ 1 görülmektedir. Şiir duygu ve düşünceleri geliştiren, coşku ve hissi arttıran edebi metindir. İnkılap Tarihi dersinin başarıya ulaşması ve derse ilginin artması adına temel öğretim materyali olan ders kitabında şiirlerden daha fazla yararlanılması gerekmektedir.

\section{Sonuç ve Öneriler}

İnkılap Tarihi dersi Türkiye Cumhuriyeti'nin kuruluşunu, tük milletinin geçirdiği sıkıntıları ve bağımsızlık adına verdiği mücadeleleri aktaran bir derstir. Bu aktarımda en temel kaynak olarak karşımıza İnkılap Tarihi ders kitabı çıkmaktadır. İnkılap Tarihi dersinin başarıya ulaşmasında edebi ürünlerin katkısı yadsınamaz. Edebi ürünler duygu, düşünce ve hayallerin sözlü ya da yazılı olarak anlatıldığı türlerdir. Anı, şiir, biyografi, nutuk, deneme, makale, tarihi ve bilimsel yazılar, günlük, masal, roman, hikaye ve demeç edebi ürünlerden bazılarıdır.

Bu çalışmada İnkılap Tarihi ders kitabındaki edebi ürünler incelenmiştir. İnkılap Tarihi ders kitabında anı, gazete, biyografi, makale, tarihi yazıların olduğu saptanmıştır. En çok bunların arasında sözlü anlatım türlerinden demeç, yazılı anlatım türlerinden nutuk, tarihi yazılar kullanılmıştır. İnkılap Tarihi ders kitabında faydaları açısından anıya, günlüklere, gazetelere, tarihsel romanlara, hikâyelere çok fazla yer verilmediği görülmüştür. Bu açıdan ders kitabının sanatsal metinler olan roman, hikâye ve şiir açısından zenginleştirilmesi gerekmektedir.

- İnkılap Tarihi ders kitabı üniteler açısından değerlendirildiğinde edebi ürünlerin üniteler arasında dengeli dağılmadığı görülmüştür. En az edebi ürüne "Bir Kahraman Doğuyor" ve "Demokratikleşme Çabaları" ünitesinde yer verildiği görülmüştür. Bu 
durum ünitelerin ele aldığı konuların detayı ve içeriği ile ilgilidir. Demeçlere "Bir kahraman Doğuyor" ünitesi hariç her ünitede yer verilmiştir. İnkılap Tarihi genel itibariyle Mustafa Kemal'e ve onun devrimlerine odaklandığ için birinci elden kaynak olarak yer verilmesi Atatürk'ün demeçlerine sıklıkla yer verilmesi kitabın bilimselliğine katkı yapmıştır. Şiire ise yalnızca "Ya istiklal Ya Ölüm" ünitesinde yer verildiği görülmüştür. Dönemin ruhunu ve milli mücadele duygusunu yaşatma açısından şiirlere daha fazla yer verilmesi fayda sağlayabilir. Kitabın geneli değerlendirildiğinde bilgilendirici edebi ürünlere yeteri kadar yer verildiği söylenebilir. Kitabın sanatsal metinler açısından da zenginleştirilmesi öğrencilerin kitaba olan ilgisini ve merakını arttıracağı düşünülmektedir. Bu çalışmanın sonuçları doğrultusunda aşağıdaki öneriler getirilebilir:

- İnkılap tarihi ders kitaplarında edebi eserlerin kullanımı daha dengeli yapılabilir. Az tercih edilen veya hiç kullanılmayan edebi eserler konu, kazanım durumu ve sınıf seviyesine göre düzenlenebilir. Bu kapsamda şiir, hikâye ve tarihsel romanlar açısından zenginleştirilebilir.

- İnkılap tarihi ders kitaplarında farklı edebi ürünlerin kullanımına ilişkin yapılacak araştırma sayısı artırılabilir.

Araştırmada kullanılan ders kitabı ve diğer ders kitaplarında öğrencilerin okuması amacıyla her bir konuya ilişkin tarihsel roman, dönemi anlatan hikâyeler gibi edebi ürün tavsiyeleri eklenebilir.

\section{Kaynakça}

Akkuş, Z. (2007). Tarih Öğretiminde Edebi Ürünlerin Kullanımının Ö̆ğrenci Başarısına Etkisi. (Doktora Tezi, Atatürk Üniversitesi, Sosyal Bilimler Enstitüsü, Erzurum). Erişim adresi: http://tez2.yok.gov.tr/.

Alaca, E. ( 2017). Sosyal Bilgiler Ders Kitapları Üzerine Bir Değerlendirme. 21. yy'da Eğitim ve Toplum, 6(18). 759- 785.

Altıkulaç, A. (2014). TC İnkılap Tarihi ve Atatürkçülük Dersinde Hatıratların Kullanımının Öğrenme Sürecine Etkisi. (Doktora Tezi, Gazi Üniversitesi Eğitim Bilimleri Enstitüsü, Ankara). Erişim adresi: http://tez2.yok.gov.tr/.

Ata, B. (2014). Sosyal Bilgilerde Atatürkçülük konularının eğitimi ve öğretmenin rolü. B. Tay ve A. Öcal (ed). Özel öğretim yöntemleriyle sosyal bilgiler öğretimi (ss. 291-306). Ankara: Pegem Akademi.

Balcı, A.(2007). Sosyal bilimlerde araştırma, yöntem, teknik ve ilkeler. Ankara: Pegem Yayincilik.

Beldağ, A. \& Aktaş, E. (2016). Sosyal Bilgiler Öğretiminde Edebi Eser Kullanımı: Nitel Bir Çalışma. Erzincan Üniversitesi, Eğitim Fakültesi Dergisi, 18(2) , 953-981.

Boyraz, E. Z. (2019). Ortaokul 8. Sınıf Türkiye Cumhuriyeti İnkılap Tarihi Ve Atatürkçülük Dersi Öğretim Programlarında ve Ders Kitaplarında Hatırat. International journal of fieldeducation, 6(1), 164- 174. 
Ceran, D. (2015). Çocuklara Rol Model Olması Bakımından Milli Mücadele Kahramanları Ve Edebi Eserlere Yansıması: “Kurtuluş Kahramanları” Kitap Dizisi Örneği. Tarihi Okul Dergisi, 8(24). 135-157.

Çalışkan, H. \& Coşkun, S. (2016). Şiirler ile sosyal bilgiler öğretimi. H. Tokcan (Ed.), Sosyal Bilgilerde Sözlü ve Yazılı Edebiyat İncelemeleri(ss. 83-110). Ankara: Pegem Akademi.

Çençen, N. \& Berk, N. A. (2014). Ortaöğretim T. C. İnkılap Tarihi Dersinde Şiir Kullanımına İlişkin Öğretmen Görüşleri”. Türk Tarih Ĕ̆itimi Dergisi, 3(1), 1-23.

Dağaşan, A. (2019). Türkiye Cumhuriyeti İnkılap Tarihi Dersinde Tarihi Günlük Kullanımının Akademik Başarıya Etkisi. EKEV Akademi Dergisi, 23(78).21-45.

Demircioğlu, İ. H. (2005). Tarih öğretiminde öğrenci merkezli yaklaşımlar. Ankara: Anı.

Dilek, A., Baysan, S. ve Öztürk, A. A. ( 2018). Türkiye'de sosyal bilgiler üzerine yüksek lisans tezleri: Bir içerik analizi çalışması. Türkiye sosyal araştırmaları dergisi, 22(2), 581602.

Doğan, Y. (2016). Hatıratlar (Anılar) ile Sosyal Bilgiler Öğretimi.H. Tokcan(Ed.), Sosyal Bilgilerde Sözlü ve Yazılı Edebiyat İncelemeleri (ss.211-235). Ankara: Pegem Akademi.

Dönmez, C., Yazıcı, K., Uslu, S. (2015). Tarih öğretmenlerine göre hatıratların eğitim öğretim sürecinde kullanılabilirlik durumları. Trakya Üniversitesi, Sosyal Bilimler Dergisi, 17(1), 255-270.

Ekiz, D. (2010). Bilimsel araştırma yöntemleri. Ankara: Anı yayıncılık

Glasser, B. (1978). Theoreticalsensitivty. SanFrancisko: Unıversity of California.

Hatipoğlu, M. (2004). "Atatürk İlkeleri ve İnklap Tarihinin Amaç ve Kapsamı", Atatürk İlkeleri ve İnkılap Tarihi'nde Yöntem Arayışları, Ankara: Hacettepe Üniversitesi Yayınları.

Karatay, H. (2007). Değer aktarımı açısından yerli ve yabancı çocuk edebiyat ürünleri, 38. ICANAS, Uluslararası Asya ve Kuzey Afrika Çalışmaları Kongresi, (10-15 Eylül 2007) Ankara.

Kaymakçı, S. (2013). Sosyal Bilgiler Ders Kitaplarında Edebi Türlerin Kullanım Durumu. Dicle Üniversitesi Ziya Gökalp Eğitim Fakültesi dergisi, 20(2013), 230-255.

MEB (Milli Eğitim Bakanlığ1 ). (2018). TC İnkılap Tarihi ve Atatürkçülük dersi Öğretim programı (ortaokul 8. Sınıf ). Erişim adresi: 201812104016155-İNKILAP TARİHİ VE ATATÜRKÇÜLÜK ÖĞRETIM PROGRAMI.pdf (meb.gov.tr).

Miles, M. B. \& Huberman, A. M. (1994). Qualitative data analysis . ThousandOaks, London: Sage Publications.

Miles, M. B. \& Huberman,A. M. (1994). Qualitative Data Analysis (2nd ed.). ThousandOaks, London: Sage Publications.

Özpek, M. (2020). Tarihi Romanlarm Sosyal Bilgiler İle Türkiye Cumhuriyeti İnkılap Tarihi Ve Atatürkçülük Dersi Öğretiminde Kullanılması Üzerine Bir İnceleme. (Yüksek Lisans Tezi, İnönü Üniversitesi Eğitim bilimleri enstitüsü, Malatya). Erişim adresi: http://tez2.yok.gov.tr/

Öztaş, S. (2018). Tarih derslerinde bir öğretim materyali: edebi ürünler. Rumeli'DE dergi ve edebiyat araştırmaları dergisi, 27(2018). 27-41.

Öztürk, A. (2002). Tarih Öğretiminde Tarihsel Romanların Kullanılması. (Yüksek Lisans Tezi, Gazi Üniversitesi, Eğitim Bilimleri Enstitüsü, Ankara). Erişim adresi: http://tez2.yok.gov.tr/

Palaz, T., Kılcan, B. \& Gülbudak, B. (2019). Türkiye Cumhuriyeti İnkılap Tarihi ve Atatürkçülük Dersine İlişkin Öğrencilerin Görüş ve Bilgi Düzeyleri: Nitel Bir Araştırma. Journal of History Cultureand Art Research, 8(1) 362-377. 
Strauss \& Corbin, J. (1998). Basic of qualitativeresearch: Grounded theoryproceduresandtechniques. Newbury Park, CA: Sage.

Sever, A. (2017). 2010 Yılında Yürürlüğe Giren Orta Öğretim Türkiye Cumhuriyeti İnkılap Tarihi Ve Atatürkçülük Dersi Öğretim Programı Ve Öğretmen Görüşleri (Samsun Örneği). (Yüksek Lisans Tezi, On Dokuz Mayıs Üniversitesi Eğitim Bilimleri Enstitüsü, Samsun). Erişim adresi: http://tez2.yok.gov.tr/

Şimşek, (2014). “Çocuk Edebiyatı Tarihine Ön söz”. Çocuk ve İlk Gençlik Edebiyatı Özel Sayıs1, Türk Dili Dergisi, 756. 16-58.

Top, M. (2009). Illköğretim 8.sınf İnkılap Tarihi ve Atatürkçülük Dersinin Öğretiminde Edebi Ürünlerin Kullanımının Öğrenci Başarısı ve Tutumuna Etkisi. (Yüksek Lisans Tezi, Marmara Üniversitesi, Eğitim Bilimleri Enstitüsü, İstanbul). Erişim adresi: http://tez2.yok.gov.tr/

Yıldırım, A. \& Şimşek, H. (2018). Sosyal Bilimlerde nitel araştırma yöntemleri. Ankara: Seçkin Yayincilik.

Yıldırım, T. \& Mert, H. (2019). Atatürkçülük Konularının Öğretimi. Çelikkaya, T., Demirbaş, Ç. Ö. , Yıldırım, T. , Yakar, H. (ed). Sosyal Bilgiler Öğretimi (ss.189-225). Ankara: Pegem Akademi.

Yılmaz, M. (2005). İlk, Orta ve Yüksek Öğretimde İnkılap Tarihi Dersleri (Amaç, İçerik, Yöntem ve Değerlendirme Boyutu)Türkiye Cumhuriyeti İnkılap Tarihi ve Atatürkçülük Konularının Öğretimi, Atatürk Araştırma Merkezi, Ankara. 